\title{
Interaction as a Key Connective Tissue of Refugee Integration in Croatian Society
}

DOI $10.17234 / 9789531756525.13$

\author{
Rahela Jurković \\ Vukovićeva 5, 10000 Zagreb, Croatia \\ rahela_jurkovic@yahoo.com \\ Marijeta Rajković Iveta \\ Department of Ethnology and Cultural Anthropology, Faculty of Humanities and Social \\ Sciences, University of Zagreb \\ Ivana Lučića 3, 10000 Zagreb, Croatia \\ mrajkovi@ffzg.hr
}

\begin{abstract}
The paper focuses on studying the experiences of integration of persons that have received international protection in the Republic of Croatia. It places emphasis on the interactive dimension of integration: the significance of social connections and relationships that these persons establish with the members of the receiving country and local community. The field research lasted for two and a half years (from 2015 to 2017) and was based on qualitative ethnological and cultural anthropological methodology. By examining the life experiences of refugees, meeting with them frequently and conducting interviews with them, the importance of the passing of time in integration was observed, as well as the importance of the moment in the research of integration processes.
\end{abstract}

Keywords: refugees, Croatia, dimensions of integration, interactive integration

\section{Introduction $^{1}$}

7 hepublic of Croatia approved its first international protection to a refugee in 2006. Between then and the end of 2017, 485 persons were granted

I international protection ${ }^{2}-337$ men and 148 women. ${ }^{3}$ The integration of persons that have received international protection, i.e. refugees in Croatian society is conditioned on the rights that they have in the Republic of Croatia, ${ }^{4}$ the effec-

1 The work is founded on the doctoral research and dissertation of Rahela Jurković (2018), created under the mentorship of Marijeta Rajković Iveta.

2 Persons under international protection are refugees who have been granted asylum or subsidiary protection (see: Zakon o međunarodnoj i privremenoj zaštiti [Act on International and Temporary Protection]).

3 See more: https://www.mup.hr/ministarstvo/dokumenti/statistika (last access 5 March 2018).

4 See: Zakon o međunarodnoj i privremenoj zaštiti. 
tiveness of the implementation of such rights and the support and assistance that governmental institutions, civil society organisations, the local community and citizens provide them in order to make them feel welcome and accepted members of society (cf. Penninx 2007; Jurković 2018).

In modern society, integration is above all a complex process, one that demands an interdisciplinary scientific approach, while the concept of integration itself "continues to be controversial and hotly debated" (Castles et al. 2002: 21). As the starting point of this cultural anthropological research, as well as of the analysis of the obtained results that was subsequently performed, we used the theoretical approaches of scholars who primarily focused on dimensions related to the integration of immigrants. Esser (2001, according to Penninx and Garcés-Mascareñas 2016: 13) refers to four dimensions of integration: "culturation (similar to socialisation), placement (position in society), interaction (social relations and networks) and identification (belonging)". Heckmann and Schnapper (2003, according to Penninx and GarcésMascareñas 2016: 13) make a distinction between structural, cultural, interactive and identificational integration. Penninx, who defined integration as "the process of becoming an accepted part of society" (2007: 10), refers to three dimensions of integration: the legal-political, the socio-economic and the cultural-religious (Penninx 2007; Penninx and Garcés-Mascareñas 2016), and three levels where the processes of integration take place: individuals, organisations and institutions (Penninx 2007: 11-12). The theory that has proven to be relevant, and which has been referred to by many researchers in the past few years (cf. Pittaway et al. 2009; Valenta and Bunar 2010; Kirkwood et al. 2014; Smith 2015), is the so-called framework that has, pursuant to literature and the implementation of qualitative research on the example of refugees in Great Britain, been derived by Ager and Strang (2004). Their theoretical framework comprises ten areas that have been identified as crucial for the integration of refugees. The authors divided these ten areas into four groups: means and markers, social connections, facilitators and foundation. Means and markers comprise four areas: employment, housing, education and health. In terms of social connections, the authors distinguish between three elements: social bondages, i.e. connections within the refugee community itself, defined through ethnic, national or religious identity; social bonds, i.e. the relationships between refugees and members of other communities; and social links, i.e. connections with institutions, including local and central government services. The term facilitators refers to language and cultural knowledge and safety and stability, while the foundation of integration consists of the area of rights and citizenship (Ager and Strang 2004). Starting from that theoretical framework, the authors have derived the following definition of integration:

"An individual or group is integrated within a society when they: achieve public outcomes within employment, housing, education, health etc. [...]; are socially connected with members of a [...] community with which they 
identify, with members of other communities and with relevant services and functions of the state; and have sufficient linguistic competence and cultural knowledge, and a sufficient sense of security and stability, to confidently engage in that society in a manner consistent with shared notions of nationhood and citizenship." (ibid.: 5)

European empirical research on the integration of refugees encompasses works on integration policies (Valenta and Bunar 2010), particular segments of integration (Mestheneos and Ioannidi 2002; Stewart and Mulvey 2014; Pajnik 2012; De Vroome and Van Tubergen 2010), the entrepreneurship of refugees (Wauters and Lambrecht 2008) or on certain national contexts: Belgium (ibid.), Norway and Sweden (Valenta and Bunar 2010), the Netherlands and other countries of the European Union (Mestheneos and Ioannidi 2002). The global refugee problem, which also has an impact on the situation in Croatia, has increasingly started drawing the interest of Croatian authors in the last ten or so years (Benčić et al. 2006), whether in the context of the protection of the rights of refugees at the level of the European Union (Baričević 2014, 2015), the tenth anniversary of the development of the asylum system in Croatia (Župarić-Iljić 2013), media depictions of asylum seekers and refugees and Croatian citizens' attitudes towards them (Župarić-Iljić and Gregurović 2013; Gregurović et al. 2016), the security systems of facilities that accommodate them and the surveillance of asylum seekers (Pozniak and Petrović 2014), foreign unaccompanied minors (Župarić-Iljić and Mlinarić 2015), biopolitics and refugees (Petrović 2016), or integration of asylees (Jurković and Rajković Iveta 2016). The previously listed studies of the European and Croatian context of international protection system offered us insights into the researched segments of the condition of refugees and into the various research approaches that are necessary in order to obtain a comprehensive view of this research area, insights into what society offers to people under international protection, as well as reflections on integration itself as expressed through the narrations, opinions and thoughts of the refugees. An overview of empirical research also points towards the importance of multidisciplinarity in studying the integration of refugees and immigrants in general. However, very few cultural anthropological studies have been conducted that would examine integration from the perspective of the refugees themselves, i.e. persons who have been granted international protection in the countries that have signed the Geneva Convention, on which this protection is based. Therefore, the specific goals of this work pertain to studying the integration experiences of persons who are supposed to integrate into Croatian society because they have received international protection in Croatia, with an emphasis on the interactive dimension of integration: the importance of the connections that they establish with the members of the receiving society. 


\section{Methodology and research sources}

The research was conducted with the use of the strategy of grounded theory, i.e. the method of conducting qualitative research that constructs inductive analyses from the data obtained through research and creates conceptual frameworks and theories in this manner (Charmaz 2011: 187). What this method has in common with ethnographic research is "field strategies, techniques for conducting observation, conversations, interviews and keeping records" (Škrbić Alempijević et al. 2016: 62). The starting point of the research was the collection of "rich data" (Charmaz 2011: 13) through interviews, participant observation and ethnographic case studies. In addition to semi-structured interviews, the data was also obtained through a combination of two qualitative research strategies: participant and non-participant (cf. Potkonjak 2014: 71). With the participant research strategy, the aim was to obtain knowledge by taking part in life of informants and their integration into Croatian society (for example, providing assistance to them in relation to the access to the rights they have), while the non-participant strategy was used when the aim was to create a distance from the situation being observed by refraining from interaction (for example, by observing activities that the Association of Africans in Croatia conducted in schools). During the research, media publications about the informants were also monitored and partly included in this paper.

According to Emerson, Fretz and Shaw (1995: 1), ethnographic field research presupposes that the ethnographer enters into a social setting, gets to know the people involved in it and develops ongoing relations with them, participates in the daily routines of the setting and observes everything around it. The research that is the basis of this paper was conducted between February 2015 and the end of 2017. Such a long time period allowed us to obtain insight into the integration of refugees as a dynamic process, a process that changes with time, and in which the interaction between refugees and the local community plays an important role. The two and a half years of research and many encounters, i.e. regular meetings with the informants, as well as multiple semi-structured interviews with the same persons (conducted at intervals of several months, one year or several days), provided insight into the transformation of their experiences, depending on the moment they were interviewed or the period of their lives they were referring to: arrival in Croatia, time spent waiting for asylum in reception centres, everyday life and experiences in exercising the rights they were lawfully entitled to, and their understandings of the concept of integration itself. The aim of conducting semi-structured interviews was to gain insight into the experiences of the informants as refugees in terms of the main aspects of their integration (Spradley 1979 according to Roulston 2010: 19). In this paper, we present one part of these experiences through summaries of the stories of several of the informants, selected according to the importance of the connections that they established (or did not establish) with the members of the receiving country. 
The interviewed informants arrived in Croatia after 2011. The interviews were conducted in English, French or Croatian (according to the choice of the informants). The interlocutors were selected with the aim of presenting an ethnography of the particular (Abu-Lughod 1991), in the manner of representing various countries of origin (Congo, Nigeria, Pakistan, Senegal, Syria), different professions (athlete, cook, chef, musician, lawyer), as well as different family situations (singles, families). The age of our interlocutors ranged between 19 and 35. Although our initial aim was to examine the experiences of both sexes, this proved to be difficult to accomplish. Men constituted the greater majority of our interviewees, as they were participants in various events (e.g. Refugee Day, Migrants Day, cooking workshops, African Days in Zagreb) that were related to refugees in Croatia. It turned out that men were more active and "visible" than women. In addition, some women refused to talk due to a lack of language proficiency, or due to other unnamed reasons (an interview could not be arranged with them, or they ignored the request for an interview). The interviews were arranged after a brief period of acquaintance with the informants that were included in participant observation. Some of the interlocutors were involved in two local initiatives, the culinary collective the Taste of Home ${ }^{6}$ and the Football Club Zagreb 041, ${ }^{7}$ which aimed at supporting the integration of refugees into Croatian society. Parts of this paper refer to data obtained in case studies of these two local initiatives (cf. Jurković 2018).

\section{Integration experiences of refugees in Croatia: interactions with members of the local community}

The work focuses on the interactive dimension of the integration of refugees in Croatia, from the time of their arrival in Croatia and the period while they were waiting to be granted international protection (asylum) up to the period of one, two or three years after they were granted asylee status in Croatia. Our aim was to examine the informants' experiences in interacting with the members of the local community, whether with persons employed in governmental institutions that are part of the system for providing care and assistance to asylum seekers and asylees, persons who work or volunteer for organisations that help refugees, or individuals and Croatian citizens that are not related to any of the stated groups. The informants shall be listed in the order that they are mentioned in the work, as Informant A, Informant B, Informant C, etc. We shall first present their experiences from the

5 Of all 485 persons that were granted international protection until the end of 2017, 243 were aged between 18 and 34. See more: https://www.mup.hr/ministarstvo/dokumenti/statistika (last access 5 March 2018).

6 See more about the Taste of Home in: Jurković and Rajković Iveta 2016 and Jurković 2018.

7 See more about the Football Club Zagreb 041 in: Jurković 2018. 
period while they were waiting for asylum, followed by their experiences after they had been granted asylum.

\section{Life experiences of asylum seekers in Croatia}

Upon their arrival in Croatia, the informants were accommodated in a reception centre for asylum seekers. ${ }^{8}$ In the reception centre, not all people "were the same", reported Informant A, as some of the asylum seekers engaged in theft and caused trouble. What bothered him was that all of the asylum seekers were treated equally, as if they were "all bad". Even when he would venture beyond the centre, to places frequented by young people, he would encounter the following:

"If you're an asylum seeker, if you say you're an asylum seeker [...] people don't want to communicate with you [...] People from Croatia. If you tell them that you're a refugee, they don't even want to shake your hand."

When he would tell them where he was from and what he was doing in Croatia, they would respond: "OK, you're a refugee, an asylum seeker. We don't want to talk to you". We can conclude that this Informant's first contact with Croatian society was marked with interactions where the individuals from the receiving society decided not to continue communication with him, because they would stereotypically conclude that he, as an asylum seeker, was the Other, different, and should be excluded as such because he did not fit in, because he was different (cf. Hall 1997). Such were the perceptions of asylum seekers among the local population, but our other informants also had such perceptions of themselves. As Informant B reported to journalists about the life of an asylum seeker:

"You don't have a mother, a father, a nation. Nobody speaks your language. You feel like a total nobody, worthless. The life of an asylee is such that you feel that you don't belong anywhere. You're apart. On buses, people turn away from you. In café bars, nobody wants to sit next to you. When you want to go to a club, you need documents [...] Who are you, actually? Nobody." (Žaja 2014)

Informant $\mathrm{C}$ spent two years in a reception centre. His thoughts on being labelled as an asylum seeker (cf. Zetter 1991) are also marked with an unwillingness to identify with such an identity. Here, we encounter a certain paradox: persons seeking and being granted international protection are often embarrassed to have found themselves in the situation of someone who needs protection, in which this

8 During the period of the research, there were two reception centres in Croatia: one in Zagreb and the other in Kutina. 
embarrassment primarily stems from conceptions that the members of the receiving society have about them, or from their opinion that such, primarily negative, conceptions dominate. Refusal to accept the identity of a refugee is best reflected in the interview conducted with a married couple from Syria, as reported by the husband (Informant D):

"Wherever I go, I'm a refugee [...] Whenever you think about yourself, you feel like a foreigner, and you'll never be like a citizen [...] When you look at me, you don't tell me that I'm a refugee, but I am a refugee, I am a foreigner $[\ldots] "$

adding that he "hated being a refugee". For example, when going to a town park with their children, they would feel that they were not "like the other people there, like they were at home". He explained that, though other people might not view them as foreigners, that this was how they felt. Informant D, his wife and three children waited briefly for asylum at the reception centre in Zagreb, as they were included in the European programme for relocation of refugees from Greece to other European countries. In response to the question on how they spent time at the reception centre, the Informant stated: "You can imagine how we spent the time, in one room". However, he added that the situation in Croatia was better than it had been in Greece, where they had spent several months previously. They arrived in the reception centre for asylum seekers in Zagreb in August, and at that time there were no activities that they could have involved themselves in (such as Croatian language classes or creative workshops) because it was the period of summer holidays. Only the children spent two to three hours a day in playgroups organised by UNICEF. To this, Informant D added: "I hate Croatia [Zagreb, authors' note], in summer, there's nobody here, it's really empty, I feel that it's empty. I feel isolated". The lack of employees of public and other institutions due to the annual leave, i.e. a lack of interaction with them, was what this Informant highlighted as a negative phenomenon.

Informant $\mathrm{C}$, who was a professional football player in his country of origin, started to encourage other asylum seekers to play football after he arrived at the reception centre for asylum seekers, as: "when we started playing, it didn't matter where someone was from, or what religion he belonged to", adding that they all played together. Furthermore, this was something that they did at their own initiative. In one of the interviews, he described how it once happened that policemen and other employees of the reception centre, together with people from the Red Cross who had provided them with a field for playing, watched the asylum seekers play football with great interest, which he found to be "very nice" as it was the only thing that attracted them, something they wanted to watch. He added: "the asylum seekers played with joy, the police watched them, and everybody was happy", which demonstrates the importance of interaction between asylum seekers, the local Croatian population and 
the police when it comes to leisure activities. With this, the ethnography of the particular showed that the reception centre for asylum seekers did not always have to be an "area of uncertainty" in which it is difficult to build trust between asylum seekers and the employed staff (cf. Pozniak and Petrović 2014). On the basis of interactions established in the reception centre and his work in it as a football coach, Informant $\mathrm{C}$ met the president of the local football club for which younger players (children) of Croatian origin played. He offered the Informant the position of the coach of the club, and the Informant's first reaction was to say that his Croatian was not really good, and that because of this he would not be able to communicate with the children. The president of the club retorted that this did not even matter, as "football speaks only one language". The Informant continued: "This is something I'll never forget $[\ldots]$ and that is how I started coaching the kids". He would coach the asylum seekers in the morning, and the children in the evening. Often he would miss dinner at the reception centre as it clashed with his training sessions with the children but, nevertheless, he was "very, very happy" as it was time well spent, and because he felt needed and had the opportunity to continue playing football, like he did in his country of origin. This football club forever "remained in his heart", as:

"These were people who accepted me $[\ldots]$ out of love $[\ldots]$ they loved me. They respected me as a human being, not as an asylum seeker, not as a coach that they wanted to use [...] This was something I saw in the eyes of these parents [...] When someone behaves towards me in a loving way, I can sense it $[\ldots]$ This is why I was so happy when they gave me this chance."

Therefore, he was happy at the club where he coached children because nobody perceived him as an asylum seeker, and he stressed: "Why should a human being be viewed as an asylum seeker?", adding:

"I want to be viewed just like any other Croatian citizen who lives here, as someone who goes through the same things as other people [...] If you live somewhere, try to spend time with this community, do what they do, feel both their pain and their joy; this is what it means to be integrated [...]."

From this experience, it can be observed that this Informant needed to not feel treated like a mere asylum seeker by the local community, but to be accepted for his knowledge and skills. As Pittaway et al. concluded: "People feel the need to be able to contribute to their new country, to retake control of their own lives and to regain their dignity and freedom" (2009: 144). Likewise, his desire to spend time with the members of the society into which he migrated and to understand them can also be observed.

Reception centres offered organised activities for asylum seekers with the primary aim of filling their leisure time, and not with the aim of discovering their 
knowledge, skills, talents, and finding places where they could be employed to the benefit of both asylum seekers and their new community. The case of Informant $\mathrm{C}$ represents an example of his individual strength and the need not to succumb to waiting and idleness, which was then recognised by the members of the receiving society. Only when he stepped out onto the football field did others notice him and acknowledge his abilities. Such situations do not happen often, and neither do they happen to the majority of asylum seekers. We would like to stress that Informant C was over 30 when he arrived in Croatia, in contrast to, for example, Informant A, who was in his early twenties, and thus attention should also be given to the maturity of the informants and their previous life experiences. Therefore, Informant $\mathrm{C}$, though indirectly, through his desire to continue playing his beloved sport of football, effected the establishment of interaction with members of the receiving society, which then caused the creation of new dimensions of interaction, such as social and economic.

Experiences of integrating into Croatian society after being granted asylum

The previously mentioned practices of exclusion, i.e. non-acceptance by the receiving society, for Informant A continued even after he was granted asylum and started living in Zagreb. He encountered rejection: "Even my neighbours don't want to talk to me because they know who I am, all they do is just say 'hi' from time to time". Furthermore, he held that it was difficult for him to find a job because people did not like "other skin colours". Therefore, here the question is not only of social status (asylum seekers and asylees as non-citizens or denizens, cf. Agamben 1995), but also of colour of skin, which a priori stereotypes people into the category of those you should not socialise with, or those you should be careful with. With time, the Informant A met new people, mostly volunteers of non-governmental organisations that worked with refugees, who showed him a different side to Croatian society, and whom he befriended. Therefore, his conclusion was as follows: "If you don't have friends, you can die here!"

During the research, Informant A's thoughts about his life in Croatia changed. During the first interview, he stated that it was more difficult to be an asylee than an asylum seeker, explaining this with the insufficient financial assistance that unemployed asylees received. In the second interview (after four months), he still held that good people existed in Croatia, but he also had new understandings about the citizens of Croatia: he stated that they suffered too, as they were without money and employment. He was also unemployed at that moment, although he had established contact with the culinary cooperative the Taste of Home, which gathers migrants and refugees, and cooked with them occasionally. However, he did not have the best opinion of this cooperative, as he held it to be a closed group of people that was difficult to approach. Nevertheless, he managed to find a summer job on the Adriatic 
coast through them, and later found employment in the cooperative as a cook. Informant A was also a cricket player, and he played cricket for a club from Zagreb and won awards at competitions outside of Croatia with this club. He stressed that his fellow cricket players had helped him a lot, and that he was able to count on them much more than on those who were very vocal and public about their support for the integration of asylees. In his last interview (a year and a half after the first interview), he stated that he was finally happy with his life in Croatia. However, he was not certain whether he wanted to stay in Croatia permanently. As one of the problems, he reported having searched for a place to rent for three months, commenting that people were racist and did not wish to rent him an apartment.

The example of Informant A illustrates the importance of interaction with the domicile population, which was mediated through activities conducted in the culinary cooperative and through playing cricket. Through our encounters with him during two years, we observed that the intensity of interaction with Croatian citizens was what conditioned his stance as to whether he wanted to leave Croatia or stay. The better the interaction with the local community, the more satisfied he was with his life in Croatia, and vice versa. With time, the interactive dimension proved to be strengthened and expanded, as he had found employment in the culinary cooperative, thus achieving both the social and the economic dimensions of integration. He travelled with them, which allowed him to encounter new people and regions of Croatia, which contributed to his feeling of being happy in Croatia.

Informant $\mathrm{C}$ continued coaching children after he was granted asylum, but he also received an invitation from another club, Football Club Zagreb 041, to coach the adults that were playing for this club, among whom some were asylum seekers and asylees. The Club was established in late 2014, and one of its aims was to integrate refugees. Informant $\mathrm{C}$ coached the players of this Club for more than a year, on a voluntary basis. In the interview, he stated that some of the members would tell him that he was the identity of the Club, which was something that he could not accept because that would have meant that not all members of the football club were equal, whereas his stance was as follows:

"All are equal in this Club, and no matter whether you're black or white you're a player of this team and a member of this Club, and if you don't play football well, you won't play."

In addition to coaching for Football Club Zagreb 041, Informant $\mathrm{C}$ also found employment and married a Croatian woman after he was granted asylum. After some time he stepped down from the role of coach of Football Club Zagreb 041, as he did not have enough time for all his private and business obligations. In the meantime, he also completed the coaching school of the Croatian Football Federation and continued coaching the children of Croatian citizens in the men- 
tioned local football club in Zagreb. We can conclude that, in his case as well, interaction with the local community not based on relationships related to his status as a refugee, i.e. asylee were of crucial importance for his integration.

Informant $\mathrm{D}$ and his wife were not satisfied with their lives as persons who were granted asylum in Croatia, adding that money did not play any part in it. Although they held themselves to be already integrated into Croatian society (the children attended kindergarten, and the husband was employed), they were not satisfied. They found this difficult to explain. The Informant explained that you always remembered and missed what you had at home: childhood, cousins, family. $\mathrm{He}$ stated: "It's like dying and being born again, but as adults with memories". In his country of origin, they were a rich family that led a full life and had many friends. Now, as they explained, they "could not do anything": they could not "buy a car, or go for summer holidays". They appreciated that Croatia received them, and people were kind towards them, but they wished to return to their own country. However, Informant D added that they might change their opinion in five years: "I'll probably say then that we need Croatian citizenship", because their children: "will have, by then, become Croats instead of Syrians, as their culture, friends, childhood [...] would all be in Croatia”. Already at the reception centre for asylum seekers, they established contact with a volunteer from a non-governmental organisation that offered them an apartment to rent. ${ }^{9}$ The person in whose apartment they live still helps them a lot, and always asks them: "Do you need anything? Can I help you in any way?" Informant $\mathrm{D}$, apart from possessing work experience as a lawyer in his country of origin, had also worked with international refugee organisations in Greece. These experiences, as well as the need to care for his three children together with his wife, had an influence on the speed with which he established connections with the domicile population. Soon after being granted asylum, the Informant found employment through a volunteer that published a post on her Facebook wall stating that a person who has been granted international protection was looking for a job. This post was shared further, an employer reacted to it and offered the Informant a job. However, due to a lack of proficiency in Croatian and due to a complicated procedure for recognising previously acquired qualifications, the job he received was only on a part-time basis and the salary was low. In order for the law studies that he completed in Syria to be recognised, Informant D would have to study law fulltime in Croatia for two years which was, under the circumstances that his family of five had found himself in, i.e. the necessity to provide for their basic needs with his labour, unfeasible. This experience shows that the interactive dimension of integration is exceptionally important (for example, with the help of friends and acquaint-

Persons who are granted international protection in Croatia are entitled to have their apartment rent covered by the government for two years, starting from the day that they received the decision on international protection (see: Zakon o međunarodnoj i privremenoj zaštiti). 
ances who were Croatian citizens, they were able to find a place to rent more quickly, and the Informant was able to find a job), though there still exists the pronounced subjective feeling of not belonging, as well as the memory of losing everything they had in their country of origin. Furthermore, interaction also highlights the prejudices that the members of the receiving society have about Others, regardless of their education, to which the following words of the Informant are witness:

"You know, once when I was having a friendly conversation with my boss, he told me: 'You know, I thought you were 55 or 60 years old because you were a lawyer with three kids.' He also thought that I didn't know how to use the Internet, or send an e-mail [...] He told me that he thought that I didn't have any experience $[\ldots]$ Often, people from European countries don't know anything about Syria, or about Arab countries in general."

Such realisations also show that his employer observed the world in a somewhat ethnocentric way. Therefore, we hold that conducting cultural anthropological research is of essential importance for integration that involves persons from different cultural, ethnic and religious backgrounds.

Informant $\mathrm{D}$ and his wife stated the following about their lives in Croatia:

"We started a new life here, and starting a new life is very difficult [...] We have started moving forward, and we hope we can continue in this direction [...]. The culture is different here, and we had to accept many new ideas that we might have not been open to previously, or which we hadn't even thought about $[\ldots]$ Now, we have to accept them and face them."

Upon his arrival in Croatia, Informant D opened a Facebook page in Arabic titled Asylum in Croatia. His decision was motivated by the fact that, prior to their arrival in Croatia, they tried to find out information about asylees in Croatia, but were unable to find anything in Arabic. This is why they decided to provide people with information about the situation in Croatia and life there, thus creating manifold interactive networks and transnational fields (cf. Levitt and Glick Schiller 2004) that no longer only focus on life in Croatia and life in the country of origin, but also on the lives of all of those who, as asylum seekers, happen to find themselves in Croatia. According to official documents, their number will continue to increase. ${ }^{10}$

After being granted asylum in 2012, Informant B started cooking in the cooperative the Taste of Home which, from the aspect of interaction, brought changes into

10 According to the Action Plan for Integration of Persons Who Have Been Granted International Protection for the Period from 2017 to 2019, it is expected that 625 unemployed persons that have been granted international protection will be registered with the Croatian Employment Service in 2018, and that 618 such persons will be registered in 2019 (Action Plan... 2017: 19). 
his life. He cooked for Croatian citizens at various events. According to his own words: "People would eat everything I cooked and then come back for seconds". This realisation can be interpreted as a moment in which the interactive dimension of integration was achieved, i.e. a turning point in his views of the members of the receiving society - who previously, as he clarified, had the habit of showing even overt signs of dislike just because he was black. Thus the Informant became convinced that food could change opinions and help him meet friends, and food also helped change his conceptions of Croatia as a closed-off country that was not particularly inclined towards those who were "different". Five years after these initial contacts mediated by food, he opened an African restaurant in the city centre of Zagreb together with a friend from the same country of origin. In addition to cooking, Informant B also provided assistance to asylum seekers in reception centres and, together with several Africans and the help of one non-governmental organisation, founded the Association of Africans in Croatia (Drustvo Afrikanaca u Hrvatskoj DAH) in 2014.

"[DAH] will promote social cohesion among African groups and individuals in the Republic of Croatia in order to prevent feeling the effects of isolation, social exclusion and racism [...] Promoting and presenting a positive image of Africa and its cultural values [...] Informing Africans in the Republic of Croatia on the possibility of exercising the rights and enabling the participation of its members and other Africans in the Republic of Croatia at various meetings and events pertaining to African culture and traditions as well as those that are suitable for integration into Croatian society." ${ }^{11}$

Informant $B$ was the first president of the Association. Together with other members of DAH, he implemented many activities that had an impact on the locals in the sense of informing them about Africa. Their most frequent activity was visiting primary schools, where they would tell the children about Africa, tell them African fairy tales, dance and play the traditional African instrument djembe. During one such activity, held in 2017 as part of the festival "African Fairy Tales", we witnessed Informant $\mathrm{B}$ telling the children of a Zagreb primary school about his positive and negative experiences in Croatia. He told them how, while he was sitting on a bench near the Central Train Station in Zagreb, a child approached him and started rubbing the skin of his arm. The child's mother ran up to them, apologised and explained that her daughter was a huge fan of Africa, that her sister liked to dress up as an African woman and paint her skin in a dark colour, and that therefore, in this way - by rubbing the Informant's skin - the little girl was only trying to find out whether the colour could come off, i.e. if he was really black. The Informant told the pupils that this was the happiest day for him after his arrival in Croatia, because

11 http://dah.hr/ (last access 23 October 2017). 
he saw that "a child loved Africa and black people". This story brought joy to the pupils. By telling them about his positive experiences with the local population, he created new positive interactions with the pupils that he was telling the story to. He also told them about his bad experiences during his stay at the reception centre for asylum seekers: "In Kutina, when they asked me: 'Who are you?' I told them: 'Nobody - people don't want to sell me a drink!'”, explaining that, in one café bar in Kutina, they didn't want to serve him because he was black. The school in which the members of DAH were presenting Africa on that day was the $56^{\text {th }}$ school in which they had organised such activities. The end of such meetings with children was always full of song, dance and laughter.

Informant E also cooked at the culinary collective the Taste of Home, which began as an occasional activity that later developed into a permanent and paid job. His experiences with the Taste of Home were very positive, and this meant:

"[...] a new family for me [...], a new collective, great people who I meet there and a great idea. The idea is great because it's full of messages, a new revolution for me $[\ldots]$ We share food, different food and food we eat at one plate, and it's unity, the unification of everyone, from everywhere. We can share, to show that we can do something [...] It's one of my reasons (why I am taking part in), because I see it as a big idea, good things that are for me very important, you know [...] Unity, peace, love. New family and do what you want." (Jurković and Rajković Iveta 2016: 196)

For him, the collective the Taste of Home also signifies the realisation of the identificational dimension of integration, as demonstrated by the feeling of belonging to, i.e. creating a "new family" which is also the result of the interactive aspect of his integration process. As he also found employment with this collective in the end, in addition to the interactive and identificational dimensions of integration, the collective also provided him with economic integration. With time, he finished a training programme for chef, which was funded by the Red Cross, and became chief cook in the Taste of Home. He stressed that integration, above all, depended on the persons themselves, after which other people and Croatian society played an important role in the sense of openness towards asylees. "They're welcoming, they're nice, but they need to do more $[. .$.$] " explaining that this related more to culture,$ sports, music and shows that would involve asylees and the local population:

"If the country sees me, if it trusts me and gives me a paper [grants international protection, authors' note], gives me a chance to start a new life, then I can pay them back, I can thank them [...]."

For some time, Informant E played football for the Football Club Zagreb 041, whose members, i.e. people gathered around the Club, he had met even before the 
Club was founded, as the association of football fans White Angels (Bijeli Andeli), predecessor of the Club (cf. Hodges 2015), had initiated meetings and football games with refugees and asylees a few years before the foundation of the Club. For Informant $\mathrm{E}$, these activities were of crucial importance, as through this kind of socialisation he managed to establish social connections with the local guys, which then proved to be important for his feeling of connection with what was to become the Club that he would play at. This connection, as he described it, is as strong as family, i.e. occurs on the interactive and identificational level of his integration. On the other hand, Informant $\mathrm{C}$, who was the coach of the same Club, achieved such a level in another football club, as there he felt that he was loved and respected as a human being, not as an asylum seeker. Apart from the interactive dimension, playing football for the Football Club Zagreb 041 also provided Informant E with the identificational dimension of integration as, when he met some of the people connected with the Club for the first time, the feeling between them was as if they had known each other for five years:

"We talked, we laughed, it was cool. There was human warmth there [...] this is what I respect $[\ldots]$ and so if you say organisation, I'll tell you - no, it's a family, not an organisation."

These experiences confirm the importance of interaction for integration, as well as its influence on other dimensions of integration.

Informant F, who is from Africa, and was granted asylum in 2015, often participated in meetings and events organised by the Association of Africans in Croatia. Sometimes he would sing at the concerts of the Croatian-African band or play drums at African evenings held in clubs throughout Zagreb. At the festival "African Fairy Tales", he told the children stories from Africa and proved to be an interesting and animated narrator who aimed to bring the atmosphere of the place he was talking about to life through words and gestures. He often came to the matches of the Football Club Zagreb 041, especially in 2016, when he would drum together with the other drummers on the stands while surrounded by singing fans. During our meetings, he was always happy to have the opportunity to talk to someone in French, and he was always in the mood for joking around. He viewed DAH as the initiator of cultural exchange between Africa and Europe, and as an educator and promotor of Africa in Croatian schools. When, during a meeting of DAH that the co-author of the paper participated in, the question of how much the image of the Association should be connected with refugees arose among the members of DAH, Informant F stated: "Being a refugee is not bad. It's just a label, the important thing is knowing who you are". Therefore, in contrast to the other informants, he did not have any problems in identifying as an asylee. He viewed being granted asylum in Croatia as follows: "This is the country that accepted me, and I'm proud to be 
in Croatia and to be living in Croatia. Whether the economy goes up or down, I'll be here". He was also a musician, but it didn't take him long to come to the conclusion that he could not make a living from music in Croatia. Thus he completed a training programme for forklift operator (funded by the Red Cross), and two months after the completion of the training he found a job at a company that already employed several asylees. He stressed that he worked as a forklift operator out of self-respect, to earn a living and survive, while adding "but music - music is my life". On the first day of his new job, a woman working there told him: "I know you! You play djembe with DAH at schools [...] We saw you on TV, we know you". This is why he held that DAH played a large role in his integration. In his example, the interactive dimension was established through an association that gathers Africans in Croatia, which influenced the establishment of interaction between the Association members and employers, thus also influencing the realisation of the Informant's economic dimension of integration.

\section{Concluding thoughts}

The integration of asylees into Croatian society is a dynamic process that, on one hand, depends on the quality of the institutional infrastructure that the receiving society has provided for persons under international protection, and, on the other hand, on the persons themselves. This paper, which focused on the lives of refugees as asylum seekers and their lives after being granted asylum, showed that success at establishing interactive connections with the members of the receiving society greatly depends on the persons themselves, and that the interactive dimension of integration also plays the role of connective tissue in other dimensions of integration. The interactive dimension of integration proved to be of crucial importance for the creation of "social bridges" (Ager and Strang 2004) with the local population, i.e. with individuals that became the informants' friends, or with acquaintances and individuals that were willing to help them. Interaction with the local community also proved to be of foremost importance in changing our interlocutors' attitude towards the local population: from the attitude that they didn't like Others, asylees, and black people, to the attitude that there were also good people among them. In the cases of certain refugees, it was precisely such individuals, who did not necessarily have to be connected with any governmental or non-governmental institution providing assistance in integration, that played a key role in making their lives in Croatia easier. The interactive dimension of integration was crucial in making the informants arrive at the opinion that there were people in Croatia who were willing to help. Likewise, this dimension also revealed to them the prejudices that even such good people have in relation to the countries and regions that refugees arrive from. Interaction with new friends, Croatian citizens, also proved to be of importance in finding adequate accommodation more easily, and in finding employment. 
When it comes to the other dimensions of integration (cf. Heckmann and Schnapper 2003; Penninx and Garcés-Mascareñas 2016), the identificational dimension was also prominent in the research. In this paper, it encompassed the matter of identification with the status of refugee as a person under international protection, which mostly comprised of rejection and dislike towards the position of a foreigner in society and the identity of a refugee, asylum seeker or asylee. On the other hand, identification that was acceptable to refugees occurred at the level of the collective that accepted them and which felt like family. Such collectives were football-related, i.e. sports clubs and a culinary collective that gathers refugees. Through these collectives, they entered into interactions with persons who also had refugee experience, as well as with Croatian citizens who accepted their food, played football with them or engaged in other forms of interaction with them.

Conducting research of ethnography of the particular (Abu-Lughod 1991) through a period of two and a half years proved to be of importance for observing the dynamic nature of the integration process: the changes that happen in a person's life with the passing of time, as well as the changes in their views about life in Croatia. Some of the informants participated in activities aimed at raising awareness about refugees and members of other cultures in Croatia and themselves initiated new associations and activities, such as the Association of Africans in Croatia and activities related to the presentation of Africa to schoolchildren. Interaction with children through educational stories on Africa, laughter, music and dance proved to be one of the most effective ways to eliminate stereotypes and preconceptions about Others, thus influencing the understanding that the integration of refugees is not only the international obligation of Croatia, but also a mutually beneficial interaction process in which all who are involved have something to gain.

Although the interactive and identificational dimensions of integration are subjective categories, and are not among the foremost priorities of theorists of integration, interaction with Croatian citizens proved to be of exceptional importance for integration of refugees in Croatian society, as it represented an important link with other dimensions of integration, including the socioeconomic dimension (cf. Penninx 2007). Also, interaction showed to be essential for the refugees to feel as accepted members of Croatian society. By conducting field research for a longer period of time (two and a half years), i.e. through a systematic approach that included many interactions and multiple interviews with persons who were granted international protection in Croatia (interviews that were held from a few months to one year apart), it was also possible to observe the importance of the time and moment when the research was conducted for perceptions of satisfaction and integration into the receiving society. 


\section{REFERENCES}

Abu-Lughod, Lila. 1991. "Writing Against Culture". In Recapturing Anthropology. Working in the Present. Richard G. Fox, ed. New York: School of American Research Press, 137-163.

Agamben, Giorgio. 1995. "We Refugees". Symposium. A Quarterly Journal in Modern Literatures 49/2: 114-119.

Action Plan for Integration of Persons Who Have Been Granted International Protection for the Period from 2017 to 2019. 2017. The Government of the Republic of Croatia, Office for Human Rights and the Rights of National Minorities. https://pravamanjina.gov.hr/UserDocsImages/dokumenti/ACTION\%20PLAN\%20FOR\%20 INTEGRATION\%202017-2019.pdf (last access 12 February 2018).

Ager, Alastair and Alison Strang. 2004. Indicators of Integration. Final Report. London: Home Office.

Baričević, Vedrana. 2014. "Europeizacija azilnih politika i izbjeglička prava. Razvoj hrvatskog sustava azila i zaštita izbjeglica u Hrvatskoj" [Europeanisation of Asylum Policies and Refugee Rights. Development of the Croatian Asylum System and the Protection of Refugees in Croatia]. In Stranci pred vratima Europe. Anđelko Milardović, ed. Zagreb: Pan liber, Institut za europske i globalizacijske studije, 111-136.

Baričević, Vedrana. 2015. "Izbjeglička i migracijska pitanja kao izvor trajne krize Europske unije. Neuspjeh europskih politika azila i migracija" [Refugees and Migration Issues as a Source of Permanent Crisis in the European Union. The Failure of European Asylum and Migration Policies]. Političke analize 6/23: 3-14.

Benčić, Sandra, Gordan Bosanac, Goran Miletić, Andrijana Parić and Drago ŽuparićIljić. 2006. Azil u Hrvatskoj. Integracijske politike [Asylum in Croatia. Integration Policies]. Zagreb: Centar za mirovne studije.

Castles, Stephen, Maja Korac, Ellie Vasta and Steven Vertovec. 2002. Integration. Mapping the Field. London: Home Office Online Report 28/03. http://webarchive.nationalarchives.gov.uk/20110220110833/http://rds.homeoffice.gov.uk/rds/onlinepubs1. html (last access 10 January 2017).

Charmaz, Kathy. 2011. Constructing Grounded Theory. A Practical Guide Through Qualitative Analysis. London etc.: Sage Publications.

De Vroome, Thomas and Frank van Tubergen. 2010. "The Employment Experience of Refugees in the Netherlands". The International Migration Review 44/2: 367-403.

Emerson, M. Robert, Rachel I. Fretz and Linda L. Shaw. 1995. Writing Ethnographic Fieldnotes. Chicago, London: University of Chicago Press.

Gregurević, Margareta, Simona Kuti and Drago Župarić-Iljić. 2016. "Attitudes towards Immigrant Workers and Asylum Seekers in Eastern Croatia. Dimensions, Determinants and Differences”. Migracijske i etničke teme 32/1: 91-122.

Hall, Stuart. 1997. "Spectacle of the 'Other”. In Representations. Cultural Representations and Signifying Practices. Stuart Hall, ed. London: Sage, 223-290. 
Heckmann, Friedrich and Dominique Schapper. 2003. The Integration of Immigrants in European Societies. National Differences and Trends of Convergence. Stuttgart: Lucius $\&$ Lucius.

Hodges, Andrew. 2015. White Angels Zagreb. Combating Homophobia as "Rural Primitivism". Working Paper 13. Graz: University of Graz, Centre for Southeast European Studies.

Jurković, Rahela and Marijeta Rajković Iveta. 2016. “'Okus doma’. Integracija azilanata protkana transnacionalnim procesima i promicanjem kulinarskih tradicija” ["Taste of Home". Integration of Asylees Intertwined with Transnational Processes and the Promotion of Culinary Traditions]. Studia ethnologica Croatica 28/1: 147-178.

Jurković, Rahela. 2018. Integracija osoba pod međunarodnom zaštitom u hrvatsko društvo [Integration of Persons under International Protection in Croatian Society]. PhD thesis. Zagreb: Filozofski fakultet Sveučilišta u Zagrebu.

Kirkwood, Steve, Andy McKinlay and Chris McVitti. 2014. “'He’s a Cracking Wee Geezer from Pakistan'. Lay Accounts of Refugee Integration Failure and Success in Scotland". Journal of Refugee Studies 28/1: 1-20.

Levitt, Peggy and Nina Glick Schiller. 2004. "Conceptualizing Simultaneity. A Transnational Social Field Perspective on Society". International Migration Review 38/3: 1002-1039.

Mestheneos, Elizabeth and Elizabeth Ioannidi. 2002. "Obstacles to Refugee Integration in the European Union Member States". Journal of Refugee Studies 15/3: 304-320.

Pajnik, Mojca. 2012. "Migrants as Cheap Labourers in Europe. Towards Critical Assessment of Integration". Migracijske i etničke teme 28/2: 143-163.

Penninx, Rinus. 2007. "Integration Processes of Migrants. Research Findings and Policy Challenges". Migracijske i etničke teme 23/1-2: 7-32.

Penninx, Rinus and Blanca Garcés-Mascareñas. 2016. “The Concept of Integration as an Analytical Tool and as a Policy Concept". In Integration Processes and Policies in Europe. Contexts, Levels and Actors. Blanca Garcés-Mascareñas and Rinus Penninx, eds. Cham: Springer, 11-30.

Petrović, Duško. 2016. Izbjeglištvo u suvremenom svijetu. Od političkoteorijskih utemeljenja do biopolitičkih ishoda [Refugeehood in the Modern World. From Political Theoretical Foundations to Biopolitical Outcomes]. Zagreb: Naklada Ljevak.

Pittaway, Eileen, Chrisanta Muli and Sarah Shteir. 2009. “'I Have a Voice-Hear me! Findings of an Australian Study Examining the Resettlement and Integration Experience of Refugees and Migrants from the Horn of Africa in Australia”. Refuge 26: 133-146.

Potkonjak, Sanja. 2014. Teren za etnologe početnike [Fieldwork for Apprentice Ethnographers]. Zagreb: Hrvatsko etnološko društvo, Filozofski fakultet Sveučilišta u Zagrebu.

Pozniak, Romana and Duško Petrović. 2014. “Tražitelji azila kao prijetnja” [Asylum Seekers as a Threat]. Studia ethnologica Croatica 26: 47-72. 
Roulston, Kathryn. 2010. Reflective Interviewing. A Guide to Theory and Practice. London etc.: Sage Publications.

Smith, Ria. 2015. “'Trying to Make South Africa My Home'. Integration into the Host Society and the Well-Being of Refugee Families". Journal of Comparative Family Studies 46/1: 39-55.

Stewart, Emma and Gareth Mulvey. 2014. "Seeking Safety beyond Refuge. The Impact of Immigration and Citizenship Policy upon Refugees in the UK". Journal of Ethnic and Migration Studies 40/7: 1023-1039.

Škrbić Alempijević, Nevena, Sanja Potkonjak and Tihana Rubić. 2016. Misliti etnografski. Kvalitativni pristupi i metode u etnologiji i kulturnoj antropologiji [Thinking Ethnographically. Qualitative Strategies and Methods in Ethnology and Cultural Anthropology]. Zagreb: Filozofski fakultet Sveučilišta u Zagrebu, Odsjek za etnologiju i kulturnu antropologiju, Hrvatsko etnološko društvo.

Valenta, Marko and Nihad Bunar. 2010. "State Assisted Integration. Refugee Integration Policies in Scandinavian Welfare States. The Swedish and Norwegian Experience". Journal of Refugee Studies 23/4: 463-483.

Wauters, Bram and Johan Lambrecht. 2008. "Barriers to Refugee Entrepreneurship in Belgium. Towards an Explanatory Model". Journal of Ethnic and Migration Studies 34/6: 895-915.

"Zakon o međunarodnoj i privremenoj zaštiti" [Act on International and Temporary Protection]. NN 70/15. https://narodne-novine.nn.hr/clanci/sluzbeni/2015_06_70_1328.html. NN 127/17. https://narodne-novine.nn.hr/clanci/ sluzbeni/2017_12_127_2880.html (last access 20 January 2018).

Zetter, Roger. 1991. "Labelling Refugees. Forming and Transforming a Bureaucratic Identity". Journal of Refugee Studies 4/1: 39-62.

Žaja, Tomislav (director). 2014. Putnici [Travelers]. Documentary film. Zagreb: Hrvatska radiotelevizija.

Župarić-Iljić, Drago, ed. 2013. Prvih deset godina razvoja sustava azila u Hrvatskoj (s osvrtom na sustave azila u regiji) [The First Ten Years of Development of the Asylum System in Croatia (with Review of Asylum Systems in the Region)]. Zagreb: Institut za migracije i narodnosti, Centar za mirovne studije, Kuća ljudskih prava.

Župarić-Iljić, Drago and Margareta Gregurević. 2013. "Stavovi studenata prema tražiteljima azila u Republici Hrvatskoj" [Student Attitudes towards Asylum Seekers in Croatia]. Društvena istraživanja 22/1: 41-62.

Župarić-Iljić, Drago and Dubravka Mlinarić. 2015. "Strani maloljetnici bez pratnje u Republici Hrvatskoj. Problematika učenja jezika i obrazovanja" [Foreign Unaccompanied Minors in the Republic of Croatia. The Issue of Language Learning and Education]. Migracijske i etničke teme 31/3: 333-363. 